\title{
Strategic Communication dalam Perspektif Ilmu Komunikasi
}

\author{
HELPRIS ESTASWARA \\ Fakultas IImu Komunikasi, Universitas Pancasila \\ Jl. Srengseng Sawah, Jagakarsa, Jakarta Selatan 12640 \\ Telp: 081310488088, E-mail: the.estaswara@yahoo.com
}

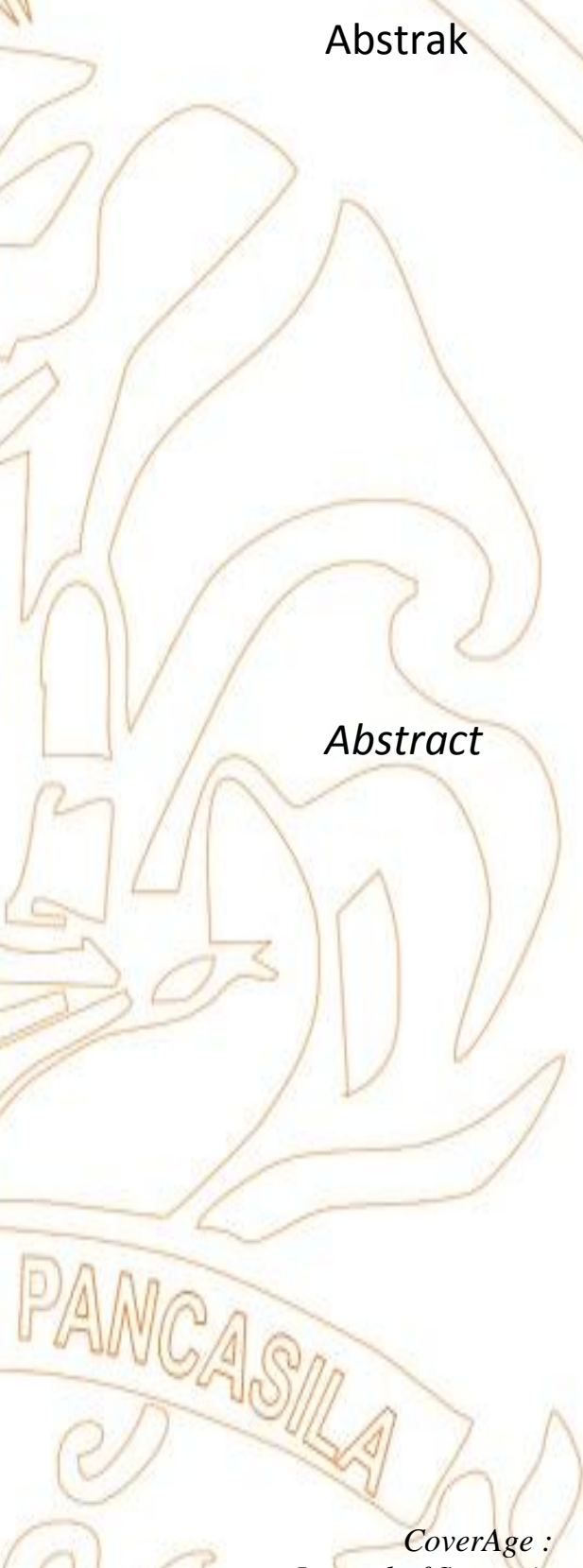

Strategic communication merupakan kajian baru dan mulai berkembang serta menjadi perhatian banyak pihak. Namun, banyak tulisan di jurnal internasional teridentifikasi belum memasukkan konsep dan teori komunikasi. Artikel ini mencoba menjelaskan strategic communication dalam perspektif ilmu komunikasi. Metode yang digunakan dalam penelitian ini adalah literatur review, mengingat banyaknya pemikir strategic communication menggagas tulisannya dengan menggunakan literatur review. Hasilnya, dari empat definisi, ditemukan bahwa strategic communication dibangun atas aktor, kemudian aksi, interaksi dan negosiasi, dan yang terakhir adalah makna. Aktor dalam strategic communication tidak hanya single actor, tetapi multiple actor. Dengan multiple actor, strategic communication akan lebih penting dan relevan. Sedangkan aksi, interaksi dan nogosiasi, di dalam strategic communication tidak hanya aksi saja, tetapi interaksi dan negosiasi menjadi bahasannya. Terakhir, makna dalam strategic communication merupakan proses dari multiple actor, di mana mereka secara bersamaan melakukan aksi, interaksi dan negosiasi.

Kata Kunci : aktor, aksi, negosiasi, makna, dan komunikasi

Strategic communication is a new study and beginning to develop and it is concern to many parties. However, many writings in international journals have not been identified as including communication concepts and theories. This article attempts to explain strategic communication from the perspective of communication science. The method used in this research is literature review, considering that many strategic communication thinkers have initiated their writings using literature reviews. The result, from the four definitions, found that strategic communication is built on actors, then action, interaction and negotiation, and the last is meaning. Actors in strategic communication are not only single actors, but multiple actors. With multiple actors, strategic communication will be more important and relevant. Whereas action, interaction and negotiation, in strategic communication, it is not only action, but interaction and negotiation are the disc ussion. Finally, meaning in strategic communication is a process from multiple actors, where they simultaneously carry out actions, interactions and negotiations.

Keywords : actor, action, negotiation, meaning and kommunication

Journal of Strategic

Communication

Vol. 11,No. 2, Hal. 77-87

Maret 2021

Fakultas Ilmu Komunikasi, Universitas Pancasila

Accepted January 13, 2021

Approved February 23, 2021 


\section{PENDAHULUAN}

Strategic communication adalah konsep yang relatif baru dalam ilmu komunikasi. Studi-studi tentang strategic communication yang berbasis ilmu komunikasi mulai banyak dilakukan sejak International Journal of Strategic Communication (IJSC) diterbitkan tahun 2017 (Thomas \& Stephens 2015, Werder et al 2018, Nothhaft et al 2018). Sampai saat ini, sudah ada 60-an judul artikel yang menggunakan "strategic communication" yang dipublikasikan di IJSC, di mana jumlah ini belum termasuk publikasi serupa di jurnal lainnya. Walau tidak semua publikasi tersebut ditulis oleh akademisi komunikasi, namun jumlah sebanyak itu-terhitung hanya dari satu jurnalmenunjukkan bahwa strategic communication telah menjadi perhatian. Mengutip Heide et al (2018), perkembangan jumlah artikel ini dikatakan sebagai bentuk academic movement yang berambisi untuk menyatukan public relations, marketing communication, organizational communication, dan berbagai disiplin ilmu lainnya yang relevan dalam satu perspektif tunggal, strategic communication (Hallahan et al 2007). Pertanyaannya kemudian, apakah "unifiying" atau "integration" saja ambisi dari pengembangan strategic communication? Tidakkah strategic communication memiliki peluang ke arah lain yang lebih menantang, dengan cara mengeksplorasi konsep dan teori dalam ilmu komunikasi?

Awalnya, konsep "strategic communication" belum diadopsi dalam kajian komunikasi. Sebelumnya, konsep ini banyak digunakan dalam kajian militer dan studi tentang hubungan internasional (international relations). Artikel ilmiah yang pertama kali menggunakan konsep strategic communication, telah dipublikasikan di jurnal Foreign Affairs saat Perang Dunia Ke-2 (PDII), dengan judul "Strategic Communication in the Middle East". Dua dekade kemudian, muncul satu artikel lagi tentang strategic communication yang diterapkan untuk menciptakan stabilitas ancaman nuklir pada masa cold war di Journal of Peace Research (Falkheimer \& Heide 2014). Sejak Hallahan et al (2007) mengenalkan strategic communication dengan menggunakan perspektif ilmu komunikasi dalam artikelnya yang berjudul "Defining Strategic Communication"-sebagai naskah utama yang dipublikasikan pada terbitan perdana IJSC (2007)-telah mendapatkan perhatian yang luas dan mendorong banyak akademisi untuk meneliti kajian baru ini dan memublikasikan hasilnya di banyak jurnal (Holtzhausen \& Zerfass 2014, Zerfass et al 2018).

Mulai saat itu, berbagai tulisan di jurnal-jurnal ilmiah (khususnya IJSC), buku-buku, dan bentuk publikasi lainnya mulai banyak diterbitkan. Tidak hanya itu, program-program pengajaran di jenjang sarjana atau pascasarjana juga banyak dibuka dengan nama "strategic communication" (Zerfass et al 2018). Menariknya, tidak demikian faktanya di Indonesia. Program studi strategic communication tidak banyak dibuka di fakultas ilmu komunikasi, selain sebatas matakuliah-itu pun tidak semuanya, hanya tercantum di beberapa kurikulum. Hal ini mengingat bahwa strategic communication kurang dipahami yang menyebabkan kajian ini menjadi tidak populer di Indonesia Umumnya, strategic communication hanya dimaknai sekedar perpaduan antara advertising (marketing communication) dan public relations.

Faktanya, sampai hari ini strategic communication telah menarik perhatian para akademisi komunikasi di dunia dengan latar belakang yang berbeda-beda, mulai dari public relations, corporate communication, organizational dan internal communication, public diplomacy, political communication, health communication, intercultural communication, advertising, sampai marketing communication (Nothhaft et al 2018). Para akademisi tersebut telah memberi kontribusi melalui berbagai penelitian empiris tentang strategic communication dengan perspektif berbeda-beda (Aggerholm \& Asmuß 2016, Aggerholm \& Thomsen 2016, Grandien \& Johansson 2016, Marchiori \& Bulgacov 2012). Literatur lain menuliskan bahwa semua perbedaan atas penelitian empiris tersebut faktanya belum memerlihatkan kejelasan arah tentang bagaimana komunikasi seharusnya menjadi pilar utama dalam kajian strategic communication (Nothhaft et al 2018, van Ruler 2018). Di sisi lain, dari berbagai penelitian yang telah dipublikasikan selama satu dekade lebih perkembangan strategic communication, penerapan teori atau konsep komunikasi masih bersifat implisit dan terlihat kabur dalam penjelasannya (van Ruler 2018).

Berangkat dari penjabaran di atas, artikel ini bertujuan untuk memahami strategic communication dari perspektif ilmu komunikasi sebagai pilar utama. Tiga hal yang dapat dilihat dalam artikel ini, yaitu aktor komunikasi, sebagai 
aksi, interaksi dan negosiasi, dan terakhir adalah makna (pemaknaan), diambil dari definisi yang diberikan oleh Argenti, Howell \& Beck (2005), Grunig (2006), Jarzabkowski et al (2007), dan Hallahan et al (2007).

\section{TINJAUAN PUSTAKA}

Strategic communication merupakan konsep yang populer di kalangan akademisi ilmu komunikasi pada dekade kedua abad ke-21 (Holtzhausen \& Zerfass 2015). Sebagai kajian baru, sejarah penelitian strategic communication dapat dikatakan masih relatif sedikit dan belum berkembang-dibandingkan dengan disiplin ilmu lainnya yang telah mapan, seperti public relations, organizational communication, advertising, maupun marketing communication-khususnya dalam memanfaatkan teori dan konsep ilmu komunikasi. Mengingat kajian ini baru berkembang satu dekade dan teridentifikasi belum terlihat nyata sebagai suatu disiplin ilmu baru, beberapa akademisi mengklaim bahwa strategic communication sebenarnya adalah kajian public relations. Namun, hasil tinjauan dari berbagai literatur menyatakan bahwa strategic communication tidak pernah dibangun untuk menggantikan disiplin ilmu apa pun (Hallahan et al 2007, Holtzhausen \& Zerfass 2015).

Banyak scholars telah mendefinisikan strategic communication dengan cara-cara yang berbeda serta dengan pengertiannya masing-masing. Seperti definisi strategic communication yang diungkapkan Argenti, Howell \& Beck $(2005,83)$ yang menyatakan bahwa "strategic communication is aligned with the company's overall strategy, to enhance its strategic positioning." Lalu Grunig, akademisi di bidang public relations, yang mengatakan bahwa strategic communication merupakan "bridging activity" antar organisasi yang harus dilembagakan (Grunig 2006). Ada pula Jarzabkowski et al., $(2007,8)$ yang mendefinisikan strategic communication sebagai "actions, interactions, and negotiations of multiple actors and the situated practices that they draw upon in accomplishing that activity". Terakhir, Hallahan et al. $(2007,3)$-definisi yang banyak dirujuk para akademisi-mendefinisikan strategic communication sebagai "the purposeful use of communication by an organization (all kind) to fulfill its mission [...]. It further implies that people will be engaged in deliberate communication practice on behalf of organizations, causes, and social movements".

Pertama, definisi Argenti, Howell \& Beck (2005) mengatakan bahwa strategic communication harus menjadi keseluruhan strategi untuk meningkatkan strategic posisitioning-nya. Mereka hanya menempatkan aktor tunggal dalam keseluruhan organisasi. Hal ini sama dengan definisi yang diungkapkan oleh Grunig (2006). Lain halnya dengan Jarzabkowski et al., (2007) dan Hallahan et al (2007) yang mengangkat aksi, interaksi dan negosiasi dari multiple actor atau kata "people" dalam definisinya. Menarik untuk dicermati penjabaran tentang strategic communication tersebut, dua pemikir menyatakan bahwa aktor dalam strategic communication adalah tunggal, sedangkan dua pemikir lainnya mengungkapkan multiple actor.

Kedua, Jarzabkowski et al., (2007) mengatakan bahwa ada aksi, interaksi dan negosiasi antar aktor dan juga praktik-praktik yang digunakan dalam strategic communication. Sedangkan Hallahan et al. (2007) menyiratkan bahwa orang akan terlibat dalam praktik komunikasi yang disengaja atas nama organisasi, causes, dan gerakan sosial. Kedua definisi tersebut pada dasarnya memiliki kesamaan makna secara komunikasi. Dalam aksi, interaksi dan negosiasi antar aktor merupakan perilaku yang ada dalam setiap organisasi, di mana dibutuhkan untuk berkembang sesuai dengan lingkungannya, baik dalam jaringan (individu, kelompok) ataupun sistem yang lebih besar (Littlejohn \& Foss 2009, 371).

Ketiga, makna (meaning) dalam definisi tersebut teridentifikasi ada dua pandangan, yaitu Argenti, Howell \& Beck (2005) dan Grunig (2006) memahami strategic communication sebagai makna yang ada dalam organisasi. Makna dalam organisasi yang dimaksud adalah semua nilai dan aturan yang berbasis pada visi dan misi organisasi. Dengan demikian, makna organisasi tersebut bisa membuat semua orang bergerak untuk memenuhinya. Namun demikian, dalam definisi Jarzabkowski et al (2007) dan Hallahan et al. (2007) mengungkapkan makna melalui aksi, interaksi dan negosiasi di mana orang-orang tidak selalu sama memberikan makna dan bahkan bisa menimbulkan konflik.

Berangkat dari definisi di atas, secara umum strategic communication bisa simpulkan sebagai 
"komunikasi yang bertujuan yang dilakukan oleh individu, kelompok atau organisasi dalam mencapai tujuan organisasi melalui aksi, interaksi dan negosiasi." Pemahaman ini banyak mengadopsi gagasan Hallahan et al., (2007) dan ditambahkan dengan memerluas "aktor komunikasi" di mana tidak terbatas pada organisasi saja (Jarzabkowski et al 2007). Berbasis pemahaman tersebut, strategic communication bisa dilihat dengan perspektif ilmu komunikasi yang berbeda-beda, seperti dari "aktor" komunikasi yang berperan, "aksi, transaksi dan negosioasi", serta dipandang sebagai "makna" (meaning).

\section{METODE}

Mendapatkan pemahaman yang holistik tentang strategic communication melalui perspektif ilmu komunikasi dapat lakukan dengan menggunakan metode literature review. Metode literatur review banyak diterapkan oleh para peneliti dalam rangka membangun sebuah pengetahuan (teori) baru, terlebih lagi bagi kajian (disiplin ilmu) yang dapat dikatakan relatif baru. Terkait dengan penelitian-penelitian strategic communication yang telah dilakukan-ketika mengeksplorasi ide atau gagasan dalam rangka membangun teori baru-para peneliti utamanya banyak menerapkan metode literatur review, seperti Ansgar Zerfass (University of Leipzig, Germany), Betteke van Ruler (University of Amsterdam), Derina R. Holtzhausen (Lamar University), Dejan Verčič (University of Ljubljana), dan Kirk Hallahan (Colorado State University).

Literature review sendiri merupakan metode yang penting dalam menulis artikel jurnal, karena tujuannya untuk memberikan pemahaman tentang state of the art atas studi yang sedang diteliti, dalam konteks ini adalah strategic communication. Hal ini digunakan untuk mengetahui sejauhmana perkembangan penelitian strategic communication dan memerkaya pengetahuan peneliti tentang penelitian-penelitian terbaru-sehingga menghambat munculnya "imajinasi ilmiah" (Hart 1998, Webster \& Watson 2002). Dengan cara seperti ini, tidak akan terjadi redudansi hasil penelitian-di mana peneliti tidak memahami bahwa penelitian serupa pernah dilakukan. Dengan menghindari hal-hal tersebut, maka tulisan ini bisa dikatakan telah memenuhi persyaratan literature review yang berkualitas sehingga hasilnya dapat memercepat proses pembangunan teori (Shaw 1995, Estaswara 2018).

Berangkat dari pemahaman tersebut, literatur review pada penelitian ini digunakan untuk meninjau berbagai publikasi ilmiah sebelumnya tentang strategic communication dengan tujuan menjelaskan topik yang diteliti dari perspektif ilmu komunikasi dalam rangka memberikan kontribusi pada arah pembangunan teori dengan cara mengeksplorasi apa saja hal-hal yang belum diteliti (Denney \& Tewksbury 2012, Bolderston 2008). Lebih lajut, penelitian ini juga menggunakan artikel-artikel yang telah dipublikasikan dalam International Journal of Strategic Communication-di mana, selama satu dekade terakhir ini menjadi rujukan para akademisi ketika berbicara tentang strategic communication. Di sisi lain, dengan mengakses jurnal-jurnal yang "trustable" tersebut dapat dikatakan juga bahwa penelitian ini telah menggunakan primary source yang merupakan syarat sebuah literature review yang dapat dipertanggungjawabkan (Bolderston 2008).

Dengan memahami strategic communication seperti di atas, pada akhirnya akan memerkaya sudut pandang, peneorian, ataupun bangunan paradigma dan metodologi dalam pengembangannya, alih-alih hanya meletakkan strategic communication dalam dominasi teori komunikasi tradisional. Ketika strategic communication dipahami sekedar perpanjangan (extension) dan penggabungan (unifying) dari disiplin ilmu advertising (marketing communication) dan public relations, maka ide-ide tentang strategic communication akan selalu didominasi oleh disiplin lain di luar bidang komunikasi-seperti strategic management. Bahkan, secara sinis, Hallahan et al., (2007) dan Dervin (1991) mengatakan bahwa cara berpikir seperti ini dianggapnya sebagai "pendekatan komunikasi nonkomunikasi" (non-communication approach to communication).

Faktanya, kajian advertising, marketing communication, public relations dan komunikasi organisasi yang selama ini dipelajari menekankan pada penetapan atas tujuan, rencana aksi, dan hasil yang dapat diukur (Shandu 2009, van Ruler 2018). Kesemuanya mendasarkan pada komunikasi sebagai aksi, pengaruh, dan hasil yang dikerangkakan dalam model transmisi/linear (van Ruler 2018). Kajian ini tidak saja sederhana dalam 
penggunaan berbagai teori komunikasi, namun juga menuntup kemungkinan pemanfaatan ilmu komunikasi dalam kajian strategic communication, alih-alih hanya memberikan peluang bagi ilmuilmu lainnya (seperti strategic management atau business management) untuk terus mendominasi konsep strategic communication. Sehingga, konsekuensi logis bagi pengembangan teorinya, ilmu komunikasi akan selalu menjadi "penumpang" dan tidak penah menjadi "supir" dalam kajian yang bernama strategic communication.

Dengan demikian, dalam penelitian ini, literature review dilakukan dengan cara mengumpulkan, memahami, menganalisis, mensintesis dan mengevaluasi berbagai jurnal (primary source), yang dilakukan secara bertahap dan juga berulang-ulang, dibandingkan dan disintesiskan secara terus-menerus, dalam rangka menjawab strategic communication dari perspektif ilmu komunikasi, guna memberikan kontribusi bagi arah pengembangan teorinya (Levy \& Ellis 2006, Estaswara 2018).

\section{HASIL DAN PEMBAHASAN}

Seperti telah diungkapkan sebelumnya, strategic communication dalam perspektif ilmu komunikasi dapat dijelaskan mulai dari aktor komunikasi. Aktor menjadi bahasan awal karena dalam konteks human communication, manusia merupakan aktor utama yang melakukan praktikpraktik komunikasi dalam rangka menjalin hubungan, saling memengaruhi, bekerjasama dan berorganisasi. Perlu dipahami bahwa komunikasi tidak mengkaji perilaku (behaviour) manusia, namun perilaku merupakan praktik komunikasi (van Ruler 2018). Setelah itu, baru "aksi, interaksi dan negosiasi", di mana semua praktik komunikasi tersebut akan terjadi mengandaikan jumlah aktor dalam ilmu komunikasi. Terakhir adalah makna (meaning) yang merupakan proses dari praktik komunikasi. Berbasis ide tersebut, dalam memahami strategic communication akan menjadi lebih variatif, di mana komunikasi bisa dilihat sebagai "actor", "aksi, interaksi dan negosiasi", dan dalam konteks "makna". Dengan cara seperti ini, lebih dimungkinkan untuk menganalisis lebih lanjut arah pengembangan teori strategic communication.

\section{Aktor dalam Strategic Communication}

Hasil tinjauan dari berbagai literatur, pemahaman tentang aktor komunikasi dalam kajian strategic communication teridentifikasi ada dua pandangan. Pertama, aktor komunikasi dalam strategic communication hanyalah manajemen atau pengelola organisasi-yang disebut sebagai single actor. Cara pandang seperti ini tidak ada bedanya dengan disiplin lain, seperti public relations, advertising, dan marketing communication, di mana public (khalayak), stakeholder atau consumer hanyalah sebagai objek komunikasi. Mereka bergerak dan tindakan komunikasinya didasarkan atas tujuan organisasi. Meskipun ada diskusi, bahkan konflik, namun mereka tetap berupaya untuk mencapai tujuan tersebut. Misalnya dalam advertising, tujuan advertising adalah mengubah minat konsumen (Estaswara 2008), maka orang-orang yang ada didalamnya akan bekerja untuk menghasilkan tujuan tersebut. Jika pun ada pertentangan di antara mereka selama pembuatan iklan, itu dianggap sebagai hal yang ceteris paribus. Contohnya lagi dalam marketing communication, ketika tujuan organisasi adalah menciptakan brand awareness (Estaswara 2008), maka orang-orang satu tim yang ada didalamnya akan bekerja keras dan detail untuk menciptakan tujuan yang telah ditetapkan. Persoalan antara bagian advertising dengan sales promotion berbeda pandangan dan bahkan terjadi konflik internal, menurut paradigma ini, itu hanyalah masalah kecil, yang pada akhirnya akan selesai semua sesuai dengan tujuan organisasi.

Menarik lagi jika public relations menangani masalah stakeholder, misalnya saat konsumen protes atas pelayanan manajemen (Estaswara 2008), maka public relations akan menyampaikan sesuai dengan tujuan perusahaan, jika di dalam tim tersebut ada perbedaan pendapat, bahkan kuat sekali, atasan akan tetap mengambil keputusan. Siapapun itu atasannya, keputusan akan tetap sesuai tujuan organisasi. Lalu, jika public relations menangani perseteruan dengan pihak luar, contohnya masyakarat sekitar, maka public relations akan melancarkan berbagai program demi tercapainya tujuan organisasi. Misalnya lagi, ketika menangani demostrasi buruh, public relations akan tetap pada tujuan organisasi, meskipun harus berunding di meja hijau sekalipun. 
Cara pandang seperti di atas, yang mengacu pada single actor, tidak akan mengubah apa pun terkait strategic communication. Strategic communication tak ubahnya hanya sebuah "penamaan baru" untuk advertising, public relations dan marketing communication, bahkan organisational communication sekalipun, meskipun terjadi unifiying atau integration didalamnya. Persoalan terjadi ketika konflik, tidak akan pernah dilihat sebagai permasalahan yang bisa mengancam tujuan perusahaan. Ketika konflik itu membesar dan berlarut-larut, atasan akan datang dan memutuskan, pakai atau buang orang tersebut. Jika tetap dipakai, maka harus diperbaiki sesuai tujuan dan aturan organisasi, jika dibuang merupakan akhir dari krisis.

Kedua, pemahaman tentang aktor dalam strategic communication adalah multiple actors, yang didalamnya ada individu, kelompok, dan organisasi, baik yang terlibat langsung atau tidak, dalam proses pencapaian tujuan organisasi. Pemahaman pandangan ini tentunya berbeda. Sebagai contoh, dalam advertising, ketika tujuan organisasi/perusahaan untuk menciptakan minat membeli konsumen (Estaswara 2008), jika terjadi konflik di dalam tim advertising ketika menangani sebuah iklan, maka konflik tersebut dipandang real atau nyata dan harus diselesaikan, demikian juga dengan marketing communication dan public relations. Ketika ada satu aktor yang memaikan peran dominan, maka yang lainnya hanyalah objek dalam komunikasi. Namun, jika ada lebih dari satu aktor dalam komunikasi yang berpartisipasi, lazimnya disebut subyek. Predikat subyek tersebut berbeda dengan objek, di mana subyek selalu menjadi penentu dan objek hanyalah sebagai sasaran komunikasi. Berpredikat subyek dapat dimaknai bahwa aktor-aktor tersebut bergerak dan bertindak sebagai penentu hasil.

Dengan melihat aktor komunikasi secara berbeda, memiliki konsekuensi logis atas bangunan teori strategic communication. Jika aktor utama dalam kajian strategic communication adalah manajemen (organisasi), maka pihak-pihak yang lain (public, stakeholder dan consumer) hanyalah receiver dari pesan komunikasi yang disampaikan oleh manajemen. Mereka tidak memiliki kuasa atas pesan dan selalu dijadikan sebagai pihak yang dipengaruhi manajemen dalam rangka mencapai tujuan organisasi. Jika demikian, maka strategic communication tak ubahnya hanyalah planned communication atau komunikasi yang direncanakan, sifatnya disengaja, dengan tujuan memengaruhi audience-terjadinya perubahan pikiran, sikap, sampai tindakan (Windahl \& Signitzer 2009).

Menariknya, cara berpikir seperti ini sebenarnya sudah dikenal sejak era 60-an, ketika social campign (public communication) mulai banyak dipelajari dan dipraktikkan (Falkheimer \& Heide 2014). Maka, satu-satunya konsekuensi bagi pengembangan strategic communication dengan cara berpikir ini hanyalah dengan menggabungkan (unifiying) atau mengintegrasikan (integrating) beberapa disiplin ilmu, seperti public relations, organizational communication, corporate communication, integrated marketing communication, dan advertising, menjadi kesatuan pemahaman yang holistik di bawah "bendera" strategic communication. Sehingga makna "strategic" bisa diartikan dari derajat penggabungan (pengintegrasian) berbagai disiplin ilmu tersebut. Jika memahami strategic communication dengan cara seperti ini, maka pengembangan teorinya hanya fokus pada eksplorasi atas determinant factor yang mampu menjadi reason d'etre tentang integrasi berbagai disiplin ilmu.

Pemikiran tersebut sangat berbeda dengan strategic communication yang memokuskan kajiannya pada multiple actors. Penerapan ilmu komunikasi tidak lagi berbasis pada planned communication yang bercirikan goal-oriented, namun bergeser menjadi proses komunikasi yang sirkuler, di mana praktik komunikasi dalam organisasi, pada kenyataannya sulit direncanakan dan dikontrol (van Ruler 2018, Winkler \& Etter 2018). Ide seperti ini lebih memberi peluang besar bagi kajian strategic communication untuk berkembang menjadi disiplin baru yang mampu melampaui gagasan-gagasan dalam planned communication. Logika ini lebih memerhatikan proses komunikasi (interaksi dan negosiasi) antar semua aktor dalam praktik organisasi. Namun, tantangan terbesar dari cara berpikir seperti ini berpotensi menjadi sekedar "wacana teoretis" tanpa dapat diimplementasikan pada tataran praktis (Winkler \& Etter 2018).

Pemikiran strategic communication yang berbasis multiple actors, tidak sekedar memberikan perspektif baru dalam pemanfaatan disiplin ilmu komunikasi, namun mengasumsikan bahwa organisasi pada dasarnya adalah komunikasi (organization as communication) 
(Cooren 2006, McPhee \& Zaug 2000). Gagasan ini berangkat dari pengertian organisasi adalah sesuatu yang abstrak, yang berada dalam pikiran manusia. Maka, komunikasi (melalui discourse) antar aktor-lah yang membentuk organisasi (Putnam et al 2009). Komunikasi, pada kenyataannya, melalui interaksi (interaction) dan negosiasi (negosiation) digunakan oleh manusia (actor) untuk mengoordinasikan tindakan (action), menjalin dan memelihara hubungan (relations), serta menjaga kelangsungan hidup organisasi (organization) (Heracleous 2006). Membangun strategic communication dengan basis logika ini akan membawa arah bangunan konseptual yang lebih kaya akan teori-teori komunikasi, seperti rules theory, systems theory, narrative theory, speech act theory, conversation analysis, phenomenology (Husserl), ethnomethodology, framing (Goffman), structuration (Giddens), maupun semiology (Barthes), dan bahkan critical discourse analysis (Fairclough) atau critical theory (Putnam et al 2009).

\section{Strategic Communication Sebagai “Aksi, Interaksi dan Negosiasi"}

Berdasarkan hasil tinjauan literatur menemukan bukti bahwa strategic communication dapat dimaknai sebagai "aksi, interaksi dan negosiasi". Dengan melibatkan aktor komunikasi, kajian strategic communication dapat dikembangkan ke dalam kerangka logika "interaksi dan negosiasi" alih-alih hanya sebagai "aksi". Komunikasi dalam pandangan "aksi" bersifat one-way yang artinya semua orang bekerja untuk tujuan organisasi kepada khalayaknya merupakan satu-satunya tujuan yang ada-seperti dalam advertising, public relations, marketing communication ataupun organisational communication-semuanya bercirikan one-way communication, di mana pesannya adalah tujuan organisasi yang diarahkan kepada khalayak umum, baik secara internal ataupun eksternal (Estaswara 2008). "Aksi" melihat pada hasil bukannya proses, maka komunikasi sebagai hasil dianggap sebagai tindakan yang bertujuan, sehingga logis jika "hasil" merupakan fokus dari komunikasi. Gagasan ini memahami komunikasi yang bertujuan untuk menimbulkan effect (pengaruh) kepada receiver sesuai dengan maksud yang diharapkan oleh sender. Tidak masalah jika "aksi" harus menjadi bagian dalam strategic communication, namun "aksi" tersebut harus dilihat juga dalam tataran individu ataupun kelompok. Individu dan kelompok dalam organisasi pada dasarnya mengelola aksi, yang akhirnya akan menjadi interaksi dan negosiasi bagi yang lainnya, demikian seterusnya hingga terjadi komunikasi yang bersifat sirkular atau two-way communication.

Komunikasi dalam pandangan "interaksi dan negosiasi" memberikan ruang kesetaraan bagi para pelaku komunikasi, sehingga pesan bukan dominasi satu pihak, di mana pihak-pihak yang lain diasumsikan "mati" - yang realitasnya hanya diposisikan sebagai penerima pesan an sich tanpa memiliki kekuasaan atas pesan, atau paling tidak hanya memiliki hak atas interpretasi pesan, itu pun dalam konteks conditioning (Estaswara et al 2020). "Aksi dan interaksi" merupakan tindakan manusia yang pada akhirnya menimbulkan "negosiasi". Negosiasi di sini bisa berbentuk keselarasan makna, namun faktanya dapat terjadi melalui proses yang panjang ataupun bahkan tidak terjadi kesepakatan apa pun. Dalam hal ini, proses menjadi fokus kajian dibandingkan dengan hasil. Hal ini penting menjadi perhatian karena strategic communication dapat berkembang dalam disiplin ilmu komunikasi jika dilihat sebagai sebuah "proses", bukan sekedar proses "linier" yang mementingkan hasil, namun proses yang dinamis dan bersifat dialogis.

Di sisi lain, negosiasi merupakan aktivitas yang fundamental dalam hubungan saling memengaruhi. Negosiasi bukan hanya terjadi antar individu, tapi juga kelompok bahkan organisasi. Negosiasi dapat diterjemahkan sebagai proses strategis yang dilakukan melalui manuver yang dirancang untuk mencapai tujuan. Pihakpihak yang terlibat dalam perundingan untuk mencapai satu atau lebih tujuan instrumental, seperti mengubah atau mempertahankan kebijakan ataupun menemukan solusi masalah yang dapat disepakati bersama (Wilson \& Putnam 1980). Negosiasi dapat juga diartikan sebagai proses di mana dua pihak atau lebih menemui konflik ketika berinteraksi take-and-give untuk mencapai kesepakatan. Kemudian, kedua belah pihak tersebut harus bekerjasama untuk mencapai kesepakatan atau memberikan solusi, di mana keduanya berpotensi memiliki resiko, yaitu pihak lain bisa memblokir atau menggangu pencapaian tujuan pihak yang lainnya. Artinya, mereka harus bekerjasama untuk mencapai tujuan individu, sementara bersaing satu sama lain untuk 
kepentingan yang benar-benar berbeda (Putnam 1989). Dalam kaitannya dengan strategic communication, aksi, interaksi dan negosiasi berjalan secara bersamaan yang harus dipandang sebagai satu-kesatuan.

Tujuan interaksi pada umumnya adalah negosiasi yang berujung pada tawar-menawar gagasan maupun tidakan, hal ini mengingat bahwa negosiasi itu terjadi pada pihak-pihak yang saling bergantung dan tidak bisa memaksakan keinginannya sendiri. Sebagai contoh, dalam organisational communication, antara manajemen dengan para pekerja. Ketika para pekerja tidak mau bekerja secara lembur, maka baiknya harus mengomunikasikan kepada manajemen, tentunya dalam situasi tawar-menawar. Biasanya, para pekerja tersebut akan tetap lembur meskipu mengalami kekalahan dalam situasi tawarmenawar. Pihak manajemen, bagaimana pun juga akan menggunakan kata "demi perusahaan" untuk membuat para pekerjanya tetap lembur. Namun demikian, tidak selalu negosiasi merupakan satusatunya tujuan dalam interaksi, bisa dikatakan merupakan bentuk "interpretatif" atau bisa juga "pemrosesan informasi" daripada tujuan interaksi itu sendiri (Wilson \& Putnam 1980). Misalnya, salah satu pihak ingin membentuk kesan sebagai lawan baru kepada pihak lainnya, atau satu pihak ingin memahami pihak yang lainnya dengan membuat rencana dan niat mereka.

Maka, komunikasi dapat dipahami sebagai pertukaran makna (simbol) yang terjadi di tingkat intra-personal, antar individu dengan berbagai posisi, antar individu dalam kelompok formal dan non-formal, antar kelompok dan keseluruhan orang yang ada di dalam organisasi, organisasi dengan organisasi, individu, kelompok ataupun organisasi lain melalui aksi, interaksi dan negosiasi. Dengan cara berpikir seperti ini, maka strategic communication tidak hanya sekedar linieritas saja, namun mampu menjelaskan berbagai realitas konflik, konsensus, sampai budaya yang terjadi dalam organisasi dan hubungannya dengan aktor-aktor (stakeholders) lainnya, secara dinamis, bottom-up dan khas (unik).

\section{Makna dalam Strategic Communication}

Komunikasi tak lepas dari pemaknaan, di mana pemaknaan bisa terjadi dalam konteks intrapersonal, interpersonal, kelompok maupun massa. Pemaknaan bisa berangkat dari ucapan (speech), teks (text), simbol, dan tindakan seseorang. Komunikasi, terlepas dari apa pun, dapat diartikan juga sebagai proses creating of meaning (Rosengren 2000). Faktanya, makna bukanlah merupakan "hak eklusif" individu, kelompok atau organisasi tertentu. Seperti pernah dikatakan oleh Littlejohn (2009, 378), bahwa "communication does not happen without meaning, and people create and use meaning in interpreting events." Mengutip Rosengren (2000, 39), pemaknaan dikatakan sebagai "whole way in which we understand, explain, feel about and react towards a given phenomenon." Gagasan tersebut pada dasarnya mengandaikan bahwa komunikasi didasarkan pada pemahaman tentang apa yang dikatakan, ditulis atau dilakukan (Cherniak 2018), yaitu tentang apa yang orang, kelompok atau organisasi maksudkan dengan kata-kata, tulisan dan tindakan tertentu. Dengan demikian, tidak dapat dipungkiri bahwa setiap individu membangun makna, dan semua kelompok serta organisasi juga membangun makna bersama.

Dalam konteks liniar atau one-way communication, makna dipaksakan untuk diterima oleh receiver. Biro iklan mendesain creative sesuai dengan makna organisasi dan tujuan perusahaan, lalu menyebarkannya melalui media demi mempengaruhi orang-orang atas makna yang tersampikan dalam iklan. Demikian juga, aktor dalam marketing communication bekerja secara telaten untuk mengombinasikan berbagai communication tools yang dideseminasikan kepada khalayak sasaran. Bagaimana pengintegrasiannya iklan, public relations, sales promotion, personal selling dan direct marketing, menjadi fokus utamanya. Tak ketinggalan, public relations secara internal menggaungkan nilai-nilai atau budaya perusahaan kepada para pekerja, dan secara eksternal mengusahakan tujuan organisasi agar bisa diterima dan dikerjakan oleh orang lain (Estaswara 2008). Ini merupakan contoh linieritas dalam program komunikasi. Pandangan seperti ini hanya menyebarluaskan makna yang dibuat oleh organisasi kepada target audience dengan tingkat penerimaan atau adopsi sebagai ukurannya. Linieritas dapat dikatakan sah atau berlaku secara umum (Hallahan et al 2007). Namun, di sini tidak ada makna individu atau kelompok, tapi hanyalah makna organisasi atau perusahaan yang berperan. Padahal, dalam strategic communication, tidak hanya makna organisasi saja, tetapi individu dan kelompok juga berpengaruh. 
Ketika individu dengan individu, individu dengan kelompok ataupun kelompok dengan kelompok, bahkan antara organisasi dengan organisasi lainnya dan organisasi dengan lingkungannya berinteraksi, di situ terdapat proses pemaknaan. Dalam setiap konteks komunikasi, mulai dari mikro sampai makro merupakan proses yang harus dilihat dan dipahami dalam strategic communication. Lebih jauh, dalam dunia yang global saat ini, makna (meaning) terindentifikasi beragam-satu hal yang sama bisa bermakna berbeda-bersamaan dengan banyaknya budaya yang berinteraksi. Tidak hanya itu, di era masyarakat modern hari ini, organisasi modern harus bisa menjadi aktor sosial penting yang masuk dan memainkan peran ke dalam berbagai diskusi, termasuk di internet, mengenai publik dan permasalahannya yang mencoba membawa organisasi ataupun yang bertentangan dengan eksistensinya (Hallahan et al 2007). Terkait dengan hal ini, banyak makna yang akan muncul dan melebur ke dalam organisasi, tidak hanya selaras (satu kata) namun makna-makna tersebut variatif. Melihat banyaknya peran dan pemaknaan yang harus dipelajari, diterima, diambil, dan bahkan dipraktikkan-ataupun tidak diambil- maka, memelajari organisasi harus tidak bisa liniar yang mengandalkan komunikasi massa.

Terkait dengan ide di atas dan relevansinya dengan studi tentang strategic communication, penting juga untuk mengkaji makna sehingga mampu menjelaskan makna-makna "tersembunyi" dibalik interaksi komunikasi, baik yang bersifat inter maupun intra organisasi. Kembali pada globalisasi, banyaknya budaya akan bertemu dan masuk ke dalam organisasi. Hal ini tidak saja cara-cara berkomunikasi yang berubah, tetapi pemaknaan atas sesuatu juga bisa berbeda. Terlebih, jika ada budaya tertentu memiliki keyakinannya sendiri (hidden aggenda), hal ini bisa membuat organisasi menjadi limbung. Ide-ide seputar pentingnya untuk melibatkan "makna tersembunyai" akan memerdalam studi tentang konflik dalam konteks strategic communication serta upaya pencapaian kesepahaman dan saling pengertian.

\section{Strategic Communication dalam Perspektif IImu Komunikasi}

Kata strategic dalam strategic communication memiliki arti yang luas. Strategic pada dasarnya bersifat strategi, di mana strategi itu haruslah dipahami dengan cara perpikir yang luas, tidak acak dan juga tidak disengaja, meskipun bisa jadi akan berdampak negatif atas pencapaian tujuan organisasi (Hallahan et al 2007). Bersifat strategi dalam hal ini adalah mengelola orang-orang, kelompok ataupun organisasi dengan semua konteks komunikasi yang ada. Bayangakan sebuah organisasi yang didalamnya ada orang-orang, kelompok dan di luar ada organisasi lain serta lingkungannya, dan semuanya melakukan aksi, tramsaksi dan negosiasi untuk memberikan makna atau memaknai, lalu bagaimana organisasi tersebut harus berstrategi? Bukankah strategi itu luas? Dengan demikian, strategic jangan diartikan dengan sempit, mengingat strategic merupakan multi-dimensional dan harus dikaji dengan konsep yang luas (Hallahan et al 2007).

Komunikasi merupakan individu, kelompok ataupun organisasi yang melakukan aksi, interaksi dan negosiasi melalui makna dan pemaknaan. Ini merupakan inti dari strategic communication. Terkait dengan strategi itu luas, maka dalam analisisnya harus memasukkan aksi, interaksi dan negosiasi dalam setiap konteks komunikasi, yaitu pada tataran individu dengan individu, antara individu dengan kelompok, kelompok dengan kelompok, kelompok dengan organisasi, individu dengan organisasi, organisasi dengan organisasi lain, ataupun organisasi dengan lingkungannya. Ini merupakan analisis yang kompleks, multidimensional dan tatarannya berbeda-beda.

Strategic communication tidak semata-mata hanya untuk memengaruhi target sasaran atau untuk menghasilkan perilaku saling pengertian antara organisasi dengan stakeholder-nya. Ini menunjukkan bahwa fokus kajian one-way communication tidak lagi berlaku. Namun demikian, pendekatan ini dimaksudkan sebagai efek kausalitas yang membuat strategic communication menjadi lebih penting. Komunikasi hari ini yang tidak hanya one-way saja, namun sudah mengarah pada two-way dan bahkan manyway communication (Estaswara 2008), yang menyebabkan communication, advertising, public relations dan organisational communication dengan cara-cara lama (paradigma linieritas) menjadi tidak teridentifikasi konteksnya. Terkait dengan hal tersebut, maka strategic communication bersifat multi-dimensional. Artinya, semua konteks komunikasi dan semua metode harus bisa dianalisis dan diteliti. 


\section{SIMPULAN}

Artikel ini menyampaikan adanya gagasan baru dalam strategic communication yang mengusung disiplin ilmu komunikasi yang dilihat dari aktor komunikasi, aksi, interaksi dan negosiasi, serta makna. Gagasan ini lebih maju dari hanya sekedar linier atau one-way communication. Strategic communication dilihat dalam pandangan sirkuler atau two-way dan many-way communication membutuhkan multiple actor, di samping itu tidak hanya aksi saja, tetapi interaksi dan negosiasi juga berperan, sehingga makna dan pemaknaan akan lebih kaya, mendalam dan kompleks.

Tidak hanya itu, terkait komunikasi antarbudaya, di mana para pekerja dari luar daerah dan bahkan luar negeri datang, hadir dan memaikan peran penting di dalam organisasi menjadi fakta yang tak bisa dipungkiri. Demikian juga dengan globalisasi, adanya internet yang membuat dunia maya menjadi penting, sudah menjadi kenyataan yang harus dijalani oleh organisasi. Hal ini tidak hanya masalah orang luar negeri yang mengakses internet dan datang kepada organisasi, namun juga individu dan kelompok di dalam organisasi juga melakukan aksi, interaksi dan negosiasi melalui internet. Dengan demikian, strategic communication juga perlu mendasarkan pada konteks komunikasi antar-budaya dan globalisasi.

\section{DAFTAR PUSTAKA}

Argenti, P.A., Howell, R.A., \& Beck, K.A. (2005). The Strategic Communication Imperative. MIT Sloan Management Review, 46(3), 82-89.

Aggerholm, H. K., \& Asmuß, B. (2016). A practice perspective on strategic communication. The discursive legitimization of managerial decisions. Journal of Communication Management, 20(3), 195-214.

Aggerholm, H. K., \& Thomsen, C. (2016). Legitimation as a particular mode of strategic communication in the public sector. International Journal of Strategic Communication, 10(3), 195-206.

Bolderston, A. (2008). Writing an Effective Literature Review. Journal of Medical Imaging and Radiation Sciences, 39, 86-92.

Cherniak, A. (2018) Understanding of Meaning as a Communication Problem, Advances in Social
Science, Education and Humanities Research, Vol. 233.

Cooren, F. (2006). Arguments for the in-depth study of organizational interactions: A rejoinder to McPhee, Myers, and Trethewey. Management Communication Quarterly, 19, 327-340.

Denney, A.S., \& Tewksbury, R.T. (2012). How to Write a Literature Review, Journal of Criminal Justice Education, DOI:10.1080/10511253.2012.730617

Dervin, B. (1991). "Information as Nonsense; Information as Sense: The Communication Technology Connection." Dalam H. Bouwman, P. Nelissen, \& M. Vooijs (Eds.), Between Offer and Supply. Amsterdam, The Netherlands: Cramwinckel, 44-59.

Estaswara, H., Halim, U., \& Ahmad, B. B. (2020) Memaknai Strategic Communication. CoverAge, 11(1), 1-11.

Estaswara, H. (2018) Tiga Dekade Perkembangan Integrated Marketing Communications (IMC): Sebuah Literatur Review. GunaHumas: Jurnal Kehumasan, 1(2), 198-213.

Estaswara, H. (2008) Think IMC: Efektivitas Komunikasi untuk Meningkatkan Merek dan Laba Perusahaan. Jakarta: Gramedia Pustaka Utama.

Falkheimer, J. \& Heide, M. (2014). From Public Relations to Strategic Communication in Sweden: The Emergence of a Transboundary Field of Knowledge. Nordicom Review, 35(2), 123-138.

Grandien, C., \& Johansson, C. (2016). Organizing and disorganizing strategic communication: Discursive institutional change dynamics in two communication departments. International Journal of Strategic Communication, 10(4), 332-351.

Grunig, J. (2006). Furnishing the Edifice: Ongoing Research on Public Relations as a Strategic Management Function. Journal of Public Relations Research, 18, 151-176.

Hallahan. K., Holtzhausen D., van Ruler, B., Verčič D., \& Sriramesh K. (2007) Defining Strategic Communication, International Journal of Strategic Communication, 1(1), 3-35. 
Hart, C. (1998). Doing a literature review: Releasing the social science research imagination. London, UK: Sage Publications.

Heracleous, L. (2006). Discourse, interpretation, organization. Cambridge, U.K.: Cambridge University Press.

Holtzhausen, D., \& Zerfass, A. (2014). "Strategic Communication: Opportunity and Chalanges in the Research Area." Holtzhausen, D.R., \& Zerfass, A. (Eds.). The Routledge Handbook of Strategic Communication. New York, NY:Routledge, 3-17.

Holtzhausen, D. R., \& Zerfass, A. (Eds.). (2014). The Routledge handbook of strategic communication. New York, NY: Routledge.

Jarzabkowski, P., Balogun, J., \& Seidl, D. (2007). Strategizing: The Challenges of a Practice Perspective. Human Relations, 60, 5-27.

Levy, Y., \& Ellis, T. J. (2006). A Systems Approach to Conduct an Effective Literature Review in Support of Information Systems Research. Informing Science Journal, 9, 181-212.

Littlejohn S. W., \& Foss K. A. (2009) Teori Komunikasi. Jakarta: Salemba Humanika.

Marchiori, M., \& Bulgacov, S. (2012). Strategy as communicational practice in organizations. International Journal of Strategic Communication, 6(3), 199-211.

McPhee, R.D., \& Zaug, P. (2000). The Communicative Constitution of Organizations: A Framework for Explanation. Electronic Journal of Communication, 10(1/2), 1-16.

Nothhaft, H., Werder, K.P., Verčič, D., \& Zerfass, A. (2018) Strategic Communication: Reflections on an Elusive Concept. International Journal of Strategic Communication, 12(4), 352-366.

Putnam, L.L., Nicotera, A.M., \& McPhee, R.D. (2009). "Communication Constitutes Organization." Dalam Putnam, L. L., \& Nicotera, A. M. (Eds.). Building theories of organization: The constitutive role of communication. London: Routledge, 1-19.

Putnam, L. L. (1989). Bargaining. International Encyclopedia of Communicatio, Vol. 1, 176-178. Amherst, PA: Oxford University Press.

Rosengren, K. E. (2000) Communication: An Introduction. Great Britain: Sage Publication.
Sandhu, S. (2009). Strategic Communication: An Institutional Perspective, International Journal of Strategic Communication, 3(2), 72-92.

Shaw, D. (1995). Bibliographic database searching by graduate students in language and literature: Search strategies, system interfaces, and relevance judgments. Library \& Information Science Research, 17(4), 327-345.

Thomas, F. \& Stephens, J. (2015). An Introduction to Strategic Communication. International Journal of Business Communication, 52(1), 3-11.

Van Ruler, B. (2018). Communication Theory: An Underrated Pillar on Which Strategic Communication Rests. International Journal of Strategic Communication, 12(4), 367-381.

Webster, J., \& Watson, R. T. (2002) Analyzing The Past To Prepare For The Future: Writing A Literature Review. MIS Quarterly, 26(2), xiii-xxiii.

Werder, K.P., Nothhaft, H., Verčič D., \& Zerfass, A. (2018). Strategic Communication as an Emerging Interdisciplinary Paradigm. International Journal of Strategic Communication, 12(4), 333-351.

Wilson, S. R., \& Putnam, L. L. (1990) Interaction Goals in Negotiation, Annals of the International Communication Association, 13(1), 374-406, DOI:10.1080/23808985.1990.11678764

Windahl, S., \& Signitzer, B. (2009) Using Communication Theory: An Introduction to Planned Communication (2 ed.) London: Sage.

Winkler, P., \& Michael Etter, M. (2018) Strategic Communication and Emergence: A Dual Narrative Framework, International Journal of Strategic Communication, 12(4), 382-398.

Zerfass, A., Verčičc, D., Nothhaftd, H., \& Werder, K P. (2018) Strategic Communication: Defining the Field and its Contribution to Research and Practice. International Journal of Strategic Communication, 12(4), 487-505. 